\title{
Arca Saraswati dari Nganjuk
}

\section{Peter Ferdinandus}

Keywords: Sarasvati, harp, goddess of water, goddess of art

\section{How to Cite:}

Ferdinandus, P. Arca Saraswati dari Nganjuk. Berkala Arkeologi, 14(2), 182-185. https://doi.org/10.30883/jba.v14i2.719

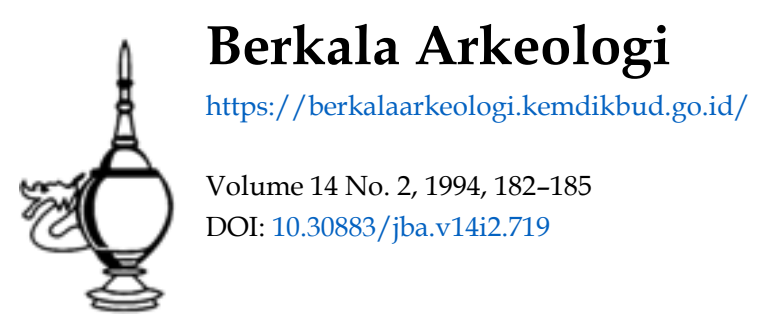

\section{(c) (7) (9)}

This work is licensed under a Creative Commons Attribution-NonCommercial-ShareAlike 4.0 International License. 


\title{
ARCA SARASWATI DARI NGANJUK
}

\author{
Peter Ferdinandus \\ (Pusat Penelitian Arkeologi Nasional)
}

\section{Pendahuluan}

Koleksi foto Oudheidkundige Dienst in $\mathrm{Ne}$ derlandsch-India terdapat foto arca Saraswati dari perunggu yang berasal dari Nganjuk (Kunst 1968, figure 45). Arca tersebut digambarkan beratribut alat musik harpa dengan lukisan makara. Arca ini menarik perhatian F.D.K.Bosch dan disimpulkan bahwa pembuat arca tersebut tidak mengenal bentuk alat musik harpa. Kesimpulan Bosch tersebut didasarkan pada penggambaran makara di bagian resonator ${ }^{1}$ alat musik harpa dimana dawai-dawainya harus berada. Harpa ini berpasak tujuh sehingga dapat diduga berdawai tujuh.

Herpa adalah merupakan alat musik petik yang terdiri dari sebuah tabung resonator berbentuk melengkung atau segitiga dengan beberapa dawai sebagai sumber bunyi (gambar 1).

Dari hasil pengamatan ternyata harpa yang didapatkan di Indonesia tidak banyak dan hanya dikenal pada abad IX dan X M pada masa Jawa Kuna.

Pengambaran bentuk harpa di Indonesia, khususnya Jawa pada masa Jawa Kuna dida. patkan pada relief-relief Candi Borobudur yaitu seri panil nomor la I, 52, dan II $1 .^{2}$ Relief Pemandian Suci Jalatunda dan arca Saraswati dari Nganjuk.

Jika diperhatikan bentuk alat musik harpa dengan penggambaran makara pada tabung resonatomya dari segi musikologi pendapat F.D.K.Bosch adalah benar. Pendapat Bosch kemudian diikuti beberapa sarjana seperti Jaap Kunst (1968), kami penulis (1985) dan Edi Sedyawati (1977).

Dalam tulisan Ferdinandus (1993) dijelaskan bahwa metode penelitian mengenai arkeomusikologi bukan saja bersumber pada metode musıkologi tetapı uga pada arkeologi. Jika diperhatikan arca Saraswati dari Nganjuk dengan jelas menunjukkan sebuah arca tokoh dewi dan bukan sebagai alat musık meskipun artibut tokoh Dewi Saraswati alat musik harpa.

Dalam konteks agama Hindu arca Saraswati dianggap sebagai perwujudan kebenaran atau perwujudan keindahan tertinggi dan sekaligus penggambaran kebenaran agama dan filsafat (Sedyawati,1985:44; Anand,1933:169).

Resonansiberarti Ihut bergetar sejalan sumber Duryi. Pemberian nomor kode yang dipergunakan dalam tulisan ini adalah berdasarkan nomor kode Leemans dan Van Erp (Krom 1920).
Oleh sebab itu dalam penelitian ini penulis tidak hanya melihat dari segi musikologi saja tetapi juga dari segi arkeologl, dengan pendekatan nas. kah-naskah yang berhubungan dengan Saraswati

\section{Bentuk Alat Musik Harpa Pada Relief Candi dan Arca}

Seperti telah disebutkan di atas bahwa harpa didapatkan pada beberapa relief dan sebuah arca. Untuk mendapat gambaran bentuk harpa di Indonesia akan diuraikan bentuk harpa yang dikenal pada masa Jawa Kuna.

Pada relief Candi Borobudur nomor seri 1 a 1 alat musik harpa didapatkan pada relief adegan Lalitawistara yang menggambarkan Bodhisattwa di surga Tusita. Alat musik ini digambarkan dalam sebuah ensambel ${ }^{3}$ yang cukup besar untuk memuja sang Bodhisatowa.

Penggambaran adegan relief tersebut dapat diketahui cara memainkan harpa dan bentuk harpa. Bentuk harpa melengkung dan berdawai dua. Cara memainkannya diletakan di atas paha kiri dan pemain duduk dalam sikap bersimpuh. Telapak tangan kiri terbuka seolah-olah dalam posisi bermain. Pemain harpa digambarkan membelakang penonton dan menghadap ke tokoh Bodhisattwa. Pemain harpa didampingi oleh pemain lute dan pemain simbal mangkuk

Pada panil 1a 52 menggambarkan para dewa berkunjung pada sang Bodhisattwa diringi sebuah ensambel, diantaranya adalah pemain harpo. Uraian dan penggambaran adegan panil tersebut dapat diketahui gambaran bentuk harpa yang melengkung dan alat musik diletakan di atas paha kiri, dipegang dengan tangan kanan. Alat musik ini terlihat beberapa pasak untuk menempatkan dawai-dawaınya. Jumlah dawainya adalah sepuluh. Pemain harpa dikelompokkan bersama pemain lute dan seorang bertepuk tangan. Hal ini menunjukkan bahwa pengaturan

\footnotetext{
${ }^{3}$ Ensambet adalah kata dambil dari bahasa Perancis "ensambte" yang berarti berkompul. Kota in kemudian dipergunakan datam musik unak menyatakan sebuah kelompok pemain musik yang bermain bersama

- Lute adalah alat musik petik yang terdiri dari beberopa dawal dua, tiga atau empot. Bertabung resononsi sepert buah peer. Musik yang dihasilkan bersifat metodi ${ }^{5}$ Simbal mangkuk bentu'vo oval dan dibuat dari pennggu. Cara memainkan harus sepasang dan saling dipukul ujung bibirmya. Musikrya dihasikan adalah Dersifat ritem
} 
kelompok musik baik yaitu perhatian unsur alat musik ritem dan melodi

Pada panil seri nomor || | Sang Bodhisattwa digambarkan dalam sebuah bangunan dan dikeliling oleh sekelompok pemain musik (ensambel di antaranya seorang pemain harpa. Dari uraian dan penggambaran adegan retief tersebut di atas didapatkan gambaran bahwa bentuk harpa adalah melengkung dengan cara memainkan diletakkan di atas paha kiri. Pemain dalam sikap duduk bersimpuh. Telapak tangan kiri terbuka seolah-olah dalam posisi bermain. Pemain menghadap Sang Bodhisattwa. Pemain harpa dikelompokkan dengan pemain lute dan simbal mangkuk dalam kelompok musik bersifat ritem dan motodi.

Uralan penggambaran bentuk harpa dan lingkungan pertunjukkan tersebut di atas menunjukkan harpa dikenal dengan baik dari sudut segi musikologi pada masa itu. Selain itu penggambaran alat musik hapa juga didapatkan pada Pemandian Suci Jalatunda, di Desa Biting, daerah Penanggungan (Jawa Timur). Bangunan ini diduga berasal dari abad X M (977 M).

Adegan pada Pemandian Suci Jalatunda tersebut menggambarkan Udayana ( 14 th.) bertemu dengan Sabara yang menyiksa seekor ular naga. Udayana memberikan gelang yang didapatkan dari ayahnya (raja Vatsa). Ular naga tersebut bebas dan sebagai gantinya Udayana diberikan sebuah harpa sakti. Karena peristiwa ini, Udayana dapat bertemu kembali dengan ayahnya (Bosch, 1945: 16-20).

Uraian relief tersebut dapat diketahui gambaran, bahwa tokoh yang dibicarakan di sini adalah tokoh Hindu dan alat musik harpa berbentuk melengkung dengan hiasan makara. Arca Saraswati dari Nganjuk digambarkan duduk di atas padma dalam sikap bersila dengan alat musik harpa diletakkan di atas pangku. Tangan kiri dalam sikap memegang alat musik dan tangan kanan dalam sikap memetik. Bentuk alat musik harpa melengkung dan berpasak 7 tetapi pada resonatornya terdapat bentuk makara sehingga tabung tersebut tertutup oleh lukisan tersebut.

Adegan relief Jalatunda menunjukkan bentuk harpe dari segi musikologi jelas menunjukkan bentuk alat musik tersebut dipandang sebagai alat musik sakti. Sedangkan arca Saraswati dari Nganjuk dari segi musikologi Jelas menunjukkan suatu kesalahan dalam penempatan makara pada tabung resonator dimana dawai-dawai harus berada.

Dengan demikian dari uraian adegan-adegan baik pada Candi Borobudur, Jalatunda dan Arca Saraswati terlihat adanya perbedaan penggambaran jumlah dawai dan variasinya. Perbedaan yang jelas sekali diperlihatkan pada arca
Saraswati yang tidak mengikuti pola bentuk harpa sebenamya.

Pada Relief Candi Borobudur menunjukkan penggambaran harpa dan lingkungan pertunjukkan dikenal benar oleh pemahat. Adegan-adegan pertunjukkan digambarkan secara realitas. Ensambel pemain musik dengan pengelompokkannya dipahatkan dengan realitas. Tokoh yang dipuja adalah Sang Bodhisattwa.

Adegen yang bersifat Hindu terlihat adanya perbedaan yang memperlihatkan unsur magi yaitu pada harpa digambarkan tokoh makara

Bentuk alat musik harpa sebenarnya tidak dipertihatkan dengan benar dari sudut segi musikologi seperti yang diperlihatkan pada relief Candi Borobudur. Tokoh-tokoh pada relief dan arca yang bersifat Hindu menunjukkan tokoh-tokoh utama seperti Udayana dan Saraswati sedangkan tokoh-tokoh pada relief Candi Borobudur tidak diketahui dengan jelas.

Arca-arca Saraswati di India pada masa India Kuna didapatkan sejak masa Kushana yaitu abad II M. (Khan 1978: PI. 1). Jika diperhatikan tulisan Khan (1978) mengenai Saraswati di India dapat diketahui bahwa arca-arca Saraswati selalu dihubungkan dengan lute. Sebab jika diperhatikan penggambaran alat musik yang dipegang Saraswati dari Gahadaval, Gorakhpur, Uttar Pradesh (sekarang di Museum Negara Lucknow), arca Saraswati dari bangunan suci Hoysalesvara di Haledid, bangunan suci Kesava, Somanathpur, Karnatak, arca Saraswati dari masa Pala (Bengal) sekarang di Museum Calcutta dan arca Saraswati dari masa Pala (abad ke 10 M.) sekarang di Museum New Delhi alat musik yang dipegang oleh Saraswati adalah iute (Khan, 1978, PI.IX, XII, XIII, dan XIV)

Jika diperhatikan alat musik dari segı musikologi adalah bar-zither atau monochord." Penggambar arca Saraswati dengan alat musik bar-zither atau monochord hingga saat ini belum didapatkan di Indonesia. Tetapi penggambaran arca Saraswati dengan lute berdawai tiga didapatkan di Jawa. Arca Ini sekarang di Museum Vienna (Kunst 1968, figure 44).

Dari uraian arca-arca Saraswati baik di Indonesia maupun di India didapatkan gambaran bahwa arca Saraswati dihubungkan di India dengan bar-zither dan dı Indonesia, khusunya dı Jawa dengan alat musik harpa dan lute. Selanjutnya dari perbandingan alat musik yang dibawakan oleh Saraswatı antara Jawa dan India

${ }^{6}$ Bar-zither adalah alat musik petik dan terdiri deri sotu dawai. Terbuat dari kay dan of unngiyo terdapat pasak tempat memutar dawai. Ruang resonatomya terletak agak ke atas dan letak-nya terpisah dar tempat danai. Musik yang dihasikan adalah Dersitat melodi. 
ternyata di Jawa didapatkan arca Saraswati membawa harpa dengan lukisan tokoh makars Oleh sebab itu dalam tulisan inı perlu diperha. tikan sumber-sumber tertulis yang berhubungan dengan Saraswati dan alat musik harpa.

\section{Saraswati Dalam Sumber Tertulis.}

Saraswati telah dikenal pertamakali dalam Rigveda I 3.12; II. 41, 16; III. 23.4; V. 42.12, 43.11; VI. 52.6; VII.36.6, 96.1-2, VIII. 21-17-18, 54.4 ; $17.7,64.9,75.5$ sebagai dewi sungai bernama Apah. Dalam kitab-kitab Ourana, Saraswati dihubungkan dengan sungai. Dalam Rigveda bukan saja dihubungkan dengan sungai tetapi juga dengan penciptaan dunia dan Prajapati (Khan, 1978:2). Prajapati dihubungkan dengan Brahma dalam kitab Puma dan Saraswati dengan vak dalam Kitab Satapatha Brahmana (II 5.4.6; III.1.4.9, 14.9.1.7.9.; IV.2.5.14, 6.33.). Dalam kitab Purana, Saraswati diciptakan oleh Brahma dan merupakan sebuah sungai yang besar yang bersumber air di gunung dan bermuara di laut. Dengan demikıan pengertian Saraswat mempunyai arti sumber inspirasi dan bersinam. bungan (Khan 1978:2)

Menurut Das Gupta sungai Indo-Brahma nama kunanya adalah Saraswati dan mengalir di antara dua pusat kebudayaan yaitu Harappa dan Mohenyodaro (Khan 1978:9). Dari segi geografi menurut Macdonell dan Keith (1958:55) lokasi Sungai Saraswati adalah Plaksa Prasrava atau distrik Patiala. Selanjutnya dari segi sejarah menurut Rigveda dan Kitab Mahabharata disebutkan bahwa suku Puru tinggal di tepi sungai Saraswati (Khan 1978: 19-20)

Saraswati darı segı pısık disebutkan dalam Rigveda buah dadanya adalah sumber kesuburan. Sebagai dewi kecantikan juga didapatkan dalam Rigveda VI 42.12. sebagai bulan purnama dengan warna putih. Dalam Rigveda Saraswati juga dihubungkan dengan dewi pengetahuan (Khan,1978:35). Dari segi aspek sosial, Saras. wati dalam Rigveda dipandang sebagai dewi sungal (Khan 1978:37-39)

Saraswati juga dihubungkan dengan beberapa dewa seperti Mitra, Dkasa, Varuna, Soma, Aswin, Maruts, Agni, India, Wisnu, Rudra, Aditya. Dalam Yajurved dihubungkan dengan sungai, dalam Athraveda, Saraswati dihubungkan dengan pengetahuan obat-obatan, sungai (Khan, 1978:7085), dan pertanian (Khan, 1978:93-94)

Dalam pengarcaan Saraswati disebutkan dalam kitab Wisnupurana, Agni, dan Matsya Purana (Khan, 1978::125). Dalam kitab Purana jumlah tangannya ada empat dan dua. Dalam Vinsupurana ia bertangan empat Dua tangan kanan memegang buku dan rosari dan tangan kiri membawa tempat air dan lute (vina) tetapi dalam Vinapustakadharini (Bhagawata Purana) ia digam- barkan bertangan dua. Yaitu memegang lute (VIna) dan buku (Khan,1978:130)

Skanda Purana menyebutkan mengapa la beratribut buku dan tempat air ? Hal tersebut disebabkan diri Saraswati pada mulanya berhu. bungan dengan air. Sedangkan hubungan Saraswati dengan lutexina disebabkan berhubungan dengan vac yang merupakan sumber bunyı Dalam Satapatha Brahmana III.2.3.4.6 disebutkan bunyi membantu manusia dalam berkonsentrasi dan dalam Satapatha Brahmana IV 1.4.1 vaca adalah sumber bunyi alat musik kendang. suling dan vina (Kunst 1968:11).

Pada masa penulis Kalidasa dalam kitab Raghuwangsa: Kumarasambhawa, Wikramorwasiva, Malawikagnimitra, Abhijnanasakuntala dan Meghaduta Sarasawti dihubungkan dengan pidato (vani). Selanjutnya dalam Raghuwangsa disebutkan Saraswati sebagai dewi kesenian dan pengetahuan. la sebagai sumber seni musik, dan sebagai guru musik (Raghuwangsa IV.6). Dalam Meghaduta dikatakan sebagai sungai (Khan,1978 150-152).

Dengan demikian dari sejarah, Dewi Saraswati selalu dihubungkan dengan sungai dan berkembang kemudian pada kitab-kitab Purana dan pada masa Kalidasa sebagai dewi kesenian. Meskipun pada masa kitab Satapatha Brahmana telah disebutkan bahwa Saraswati mempunyai hubungan dengan kesenian, khususnya alat musik.

Pemujaan kepada Dewi Saraswatı masih terlihat di India Selatan yang dikenal dengan "Ayudha Puja". Pada upacara tersebut para seniman musik, alat musik yang diupacarakan diletakkan dekat arca Saraswati. Di Bałi pemujaan kepada Saraswati dikenal pada Saraswati Odalan. Alat-alat yang berhubungan dengan Saraswati dipercikkan dengan air suci (Kasi 1974:1,2).

\section{Penutup.}

Kunst dalam tulisannya (1968:11-12) masin meragukan kata vina dengan alat musik harpa, dan lute. Dalam naskah-nasakah kesusastraan India yang telah disebutkan di atas alat musık yang mempunyai hubungan dengan Saraswati adalah vina. Dengan demikian dari segi ikonografi Saraswati di India dan Jawa didapatkan gambaran bahwa alat musik petik adalah barzither, lute dan harpa yang dipergunakan dalam pengarcaan Sarasawati, sedangkan dalam nas. kah selalu dihubungkan dengan vina. Oleh sebab itu apakah tidak mungkin pengertian alat musik vina yang dipergunakan oleh Sarasawati adalah berupa harpa, lute atau bar-zither

Pada ikonografi India, tangan kiri Saraswati digambarkan memegang tempat air yang selanjutnya dihubungkan peranan Saraswati dengan 
sungai. Sedangkan arca Saraswati dari Ngajuk tdak memperlihatkan atribut tersebut tetapi menunjukkan penggambaran makare. Sebab Makara dalam tulisan Bosch (1951) selalu dihubungkan dengan binatang air. Oleh sebab itu apakah tidak mungkin penggambaran arca Saraswati dari Nganjuk bukan saja menunjukkan penggambaran Saraswati sebagai dewi kesenian tetapi sebagai lambang dewi air juga, sehingga arca tersebut tidak dapat dipandang dari segi musikologi tetapi juga latar belakang sejarah perkembangan tokoh dewi Saraswati itu sendiri Oleh sebab itu arca Saraswati dari Nganjuk lebih menunjukkan sebuah lambang pemuja dewi Saraswati sebagai dewi air dan kesenian. 